University of Nebraska - Lincoln

DigitalCommons@University of Nebraska - Lincoln

Agronomy \& Horticulture -- Faculty Publications

Agronomy and Horticulture Department

$11-1990$

\title{
Defoliation Effects on Production and Morphological Development of Little Bluestem
}

\author{
J. J. Mullahey \\ University of Nebraska-Lincoln \\ Lowell E. Moser \\ University of Nebraska-Lincoln, Imoser1@unl.edu \\ Steven S. Waller \\ University of Nebraska-Lincoln, swaller1@unl.edu
}

Follow this and additional works at: https://digitalcommons.unl.edu/agronomyfacpub

Part of the Plant Sciences Commons

Mullahey, J. J.; Moser, Lowell E.; and Waller, Steven S., "Defoliation Effects on Production and Morphological Development of Little Bluestem" (1990). Agronomy \& Horticulture -- Faculty Publications. 343.

https://digitalcommons.unl.edu/agronomyfacpub/343

This Article is brought to you for free and open access by the Agronomy and Horticulture Department at DigitalCommons@University of Nebraska - Lincoln. It has been accepted for inclusion in Agronomy \& Horticulture -Faculty Publications by an authorized administrator of DigitalCommons@University of Nebraska - Lincoln. 


\title{
Defoliation effects on production and morphological devel- opment of little bluestem
}

\author{
J.J. MULLAHEY, S.S. WALLER, AND L.E. MOSER
}

\begin{abstract}
Response of key warm-season grasses to time, frequency, and duration of defoliation is needed to develop grazing systems for the Nebraska Sandhills. A 3-year (1986 to 1988) study was conducted on a Valentine fine sand (mixed, mesic Typic Ustipsamments) at the Gudmundsen Sandhills Laboratory near Whitman, Nebraska, to determine the effect of defoliation on little bluestem [Schizachyrium scoparium (Michx.) Nash]. Treatments were: 1 defoliation (to $7 \mathrm{~cm}$ ) on 10 June, 10 July, or 10 Aug.; 2 defoliations on 10 June and 10 Aug.; and 3 defoliations on 10 June, $10 \mathrm{July,} \mathrm{and} 10$ Aug. Control plants were harvested only at the end of the growing season (October). All plots receiving summer defoliation were harvested in October to obtain aftermath yield. Treatments were initiated in 1986, 1987, and 1988 and the effects of 1,2 , and 3 years of defoliation on dry matter (DM) yield, bud and tiller numbers, and tiller weight were measured. Experimental design was a split block with 4 plants as replications. In the first year of treatment annual DM yield from control plants was 2 times greater than that from all defoliated plants, but bud and tiller numbers were similar. In the second year of treatment, all treatments reduced annual DM yield and morphological development below that of the control if precipitation was subnormal, but not if precipitation was above normal. In the third year of defoliation, with above-normal precipitation, single June or July defoliations produced DM yields and morphological development similar to that of the control, but single August or multiple defoliations generally reduced yield and development. Little bluestem may not persist if exposed to multiple, close defoliations during the growing season.
\end{abstract}

Key Words: clipping frequency, plant yield, persistence

Growth and development of range grasses is influenced by environmental dynamics as well as time, frequency, and duration of defoliation. Highest yield of blue grama [Bouteloua gracilis (H.B.K.) Lag. ex Steud.] resulted from clipping in June or July with earlier and later defoliations giving lower total yields (Turner and Klipple 1952). Owensby et al. (1974) reported that as clipping frequency of big bluestem (Andropogon gerardii Vitman) increased ( 1 to 5 times), herbage yield decreased following 1 year of defoliation. One to 3 defoliations reduced total seasonal yield and tiller numbers of sand lovegrass [Eragrostis trichodes (Nutt.) Wood] below that of unclipped plants. Late summer and multiple defoliations resulted in the highest plant mortality (Moser and Perry 1983).

Defoliation at early growth stages of bluebunch wheatgrass [Pseudoroegneria spicata subsp. spicata (Pursh) A. Love] was less damaging to forage production than clipping at mid-season (Stoddart 1946). Herbage yields of western wheatgrass [Pascopyrum smithii (Rydb.) A. Love] were severely lowered by multiple defoliations, with unclipped plants yielding $60 \%$ more than clipped plants (Buwai and Trlica 1977). Clipping at 4-week intervals produced

\footnotetext{
Authors are assistant professor, Wildlife and Range Science Department, Southwest Florida Research and Education Center, Immokalee, Fla., 33934; and professors, Department of Agronomy, University of Nebraska, Lincoln 68583. At the time of this research the senior author was a graduate research assistant.

Research was funded by the Anna H. Elliot fund. Published as Paper 9037, Journal Series, Nebraska Agriculture Research Division.

Manuscript accepted 8 March 1990.
}

greater yields of 'Jose' tall wheatgrass [Thinopyrum ponticum (Podp) Barkw. \& D.R. Dewey] than clipping at 1- or 2-week intervals (Undersander and Naylor 1987). Additional studies have reported reduced herbage yields when clipping frequency was increased (Dwyer et al. 1963, Reed and Dwyer 1971). Similar information on little bluestem [Schizachyrium scoparium (Michx.) Nash], which contributes substantially to the forage resource of the Nebraska Sandhills, is lacking.

The objectives of this study were (1) to determine the effect of time, frequency, and duration of defoliation on little bluestem annual dry matter (DM) yield and (2) to determine the effect of defoliation schemes on bud and tiller development.

\section{Materials and Methods}

The experiment was conducted at the Gudmundsen Sandhills Laboratory near Whitman, Nebraska, from 1986 through 1988 on a Valentine fine sand (mixed, mesic Typic Ustipsamments) with native vegetation in good to excellent range condition. The study site had not been grazed for 10 years before the experiment.

Treatments were: 1 defoliation to a stubble height of $7 \mathrm{~cm}$ on 10 June (vegetative stage), 10 July (early elongation stage), or 10 Aug. (boot to early head stage); 2 defoliations on 10 June and 10 Aug.; and 3 defoliations on $10 \mathrm{June}, 10 \mathrm{July}$, and $10 \mathrm{Aug}$. Control plants were defoliated only at the end of the growing season (October); the other treatments were harvested in October to determine aftermath yield. Each treatment was applied to 4 plants (replications). Annual yield consisted of forage harvested during the growing season plus that harvested in October. Treatments were initiated in 1986, 1987, and 1988 and the effect of 1,2, and 3 years of defoliation was evaluated. Bud and tiller numbers were determined from plants excavated in October. Tillers of more than $2.5 \mathrm{~cm}$ in height were considered current year's growth. Tiller weight was determined by dividing the annual DM yield per plant by the total number of tillers. Buds located on the stem base consisted of meristematic tissue less than $1 \mathrm{~cm}$ long which had not differentiated into a tiller. Clipped plant material was sorted, previous year's dead material discarded, and all current year's growth dried at $60^{\circ} \mathrm{C}$ for $48 \mathrm{~h}$ to determine DM yield.

Experimental design was a split-block with year the main plot and treatment the sub-plot. Data were analyzed using the General Linear Models procedure (SAS 1982) with treatment means for the 3-year cumulative period (1986 through 1988) and 2-year period $(1986+1987,1987+1988)$ separated using Fischer's F-protected L.S.D. Treatment means for a single year of defoliation (1986, 1987 , or 1988) were pooled over years and separated using single degree of freedom contrasts if the year $\times$ treatment interaction was not significant. Single degree of freedom contrasts were determined for: control vs other treatments, single/vs. multiple defoliation, June vs July and June vs July and August (single defoliations), and 2 vs 3 defoliations. If the year $X$ treatment interaction was significant, the treatment means within years were separated by $t$-tests (SAS 1982). Differences among treatments were declared significant at $p=0.10$. 


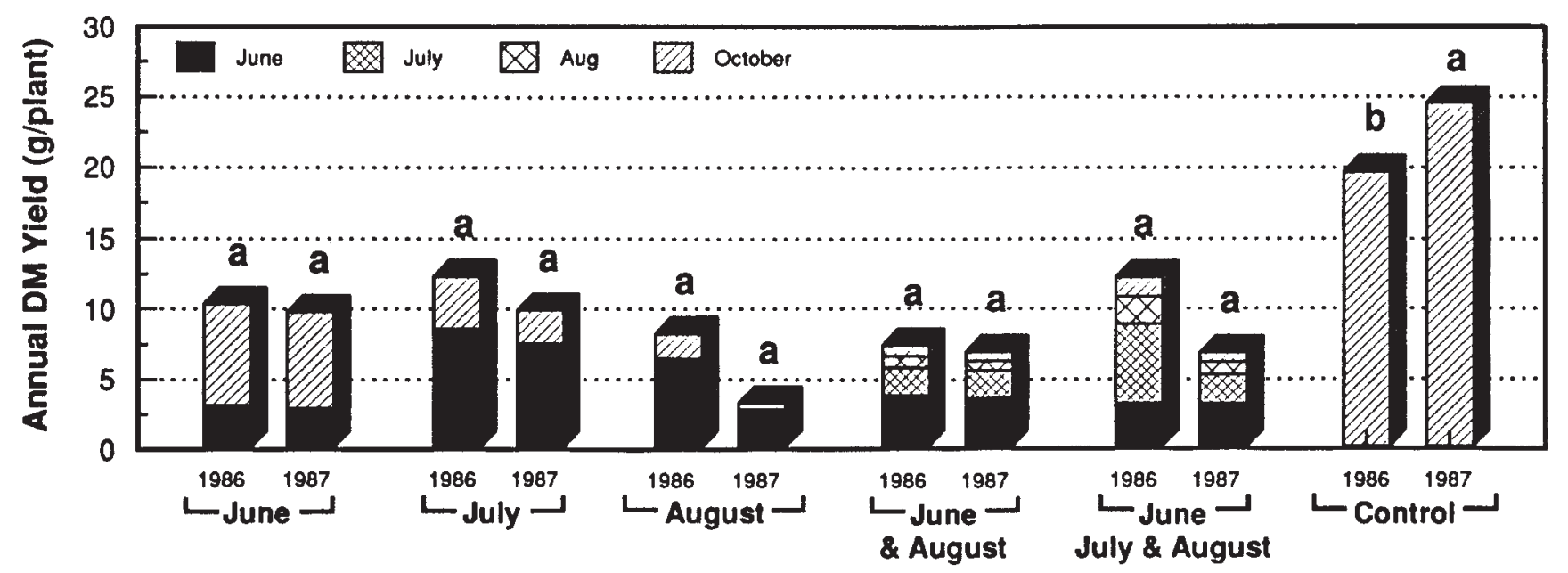

Date of Defoliation

Fig. 1. Annual dry matter (DM) yield of little bluestem defoliated on different dates for 2 years, 1986 and 1987 . Bars within defoliation scheme having the same letter are not significantly different at the 0.01 level as determined by Fischer's F-protected L.S.D.

\section{Results and Discussion}

Initial Year of Treatment

No significant year $X$ treatment interaction occurred for any response variable during the first year of defoliation $(1986,1987$, or 1988). Annual DM yield was higher for control plants than for any defoliation treatment with no differences among treatments (Table 1). Similarly, control plants were higher in tiller weight. No differences existed among defoliation treatments for bud and tiller numbers and tiller weight.

Table 1. Annual dry matter (DM) yield and morphological development of little bluestem averaged over three 1-year periods (1986 to 1988) of defoliation at the Gudmundsen Sandhills Laboratory.

\begin{tabular}{lcccr}
\hline \hline & $\begin{array}{c}\text { Annual } \\
\text { DM } \\
\text { yield } \\
\text { (g/plant) }\end{array}$ & $\begin{array}{c}\text { Tiller } \\
\text { weight } \\
\text { (mg/tiller) }\end{array}$ & $\begin{array}{c}\text { No. } \\
\text { buds/ } \\
\text { plant }\end{array}$ & $\begin{array}{r}\text { No. } \\
\text { tillers/ } \\
\text { plant }\end{array}$ \\
Treatment & 46.3 & 369 & 453 & 136 \\
Control & 19.5 & 237 & 317 & 93 \\
June & 18.7 & 181 & 405 & 131 \\
July & 18.2 & 142 & 389 & 118 \\
Aug. & 16.4 & 118 & 443 & 166 \\
June, Aug. & 13.3 & 126 & 347 & 110 \\
June, July, Aug. & & & & \\
Contrasts & $<.05$ & $<.01$ & .16 & .30 \\
Control vs others & .20 & .24 & .39 & .14 \\
Single vs multiple & .37 & .48 & .17 & .11 \\
June, Aug. vs June, July, Aug. & .65 & .22 & .16 & .15 \\
June vs July, Aug. & .78 & .34 & .61 & .34 \\
July vs Aug. & & & &
\end{tabular}

All defoliations of little bluestem in the year of initiation were detrimental to annual DM yield and tiller weight but not to bud and tiller number. Dry matter production from regrowth was influenced by phenology of the plant when defoliation occurred (Gilbert 1976). Defoliation that removed the growing points caused further growth to come from axillary buds and delayed and reduced plant regrowth. Clipping Sandhills warm-season grasses at early harvest dates resulted in regrowth of primarily vegetative shoots with few fertile shoots (Gilbert 1976).

Bud and tiller numbers were not significantly different between defoliated and control plants following 1 year of treatment (Table 1). Counting buds on little bluestem was difficult because of the inherent problems of locating buds at the stem base and determining if a bud was alive or dead. Also, natural variation in morphological development existed: some plants were fully developed prior to defoliation while other plants were still developing when defoliated. This natural variation implied that a range in response to defoliation occurs within a species.

\section{Two Years of Defoliation}

\section{6 and 1987}

In 1987 annual DM yield of control plants $(24.4 \mathrm{~g} /$ plant $)$ was higher than that of plants defoliated in 1986 and 1987 (Table 2). Defoliation treatments did not differ significantly. All treatments declined in yield following the first year of defoliation (Fig. 1). A single June defoliation produced the most aftermath ( $7 \mathrm{~g} /$ plant) by the end of the growing season while the single August and multiple defoliations produced the least ( 1 to $2 \mathrm{~g}$ /plant).

Bud numbers of little bluestem plants were reduced by all defoliation treatments (Table 2). The same was true of tiller numbers. Tiller weight was highest for control plants $(277 \mathrm{mg} / \mathrm{plant})$ although tiller weight from a single June defoliation ( $169 \mathrm{mg} /$ plant) was similar. A single August defoliation produced the lowest mean tiller weight ( $37 \mathrm{mg} /$ plant) in the second year.

\section{7 and 1988}

In 1988, all treatments defoliated in 1987 and 1988 were similar in annual DM yield to control plants $(22.4 \mathrm{~g} /$ plant $)$ except for the single August defoliation ( $11.7 \mathrm{~g} /$ plant) and 3 defoliations (8.3 $\mathrm{g} /$ plant), which were less (Table 2). All treatments declined in annual DM yield from year 1 to year 2 except the single August treatment and the control (Fig. 2). The single August defoliation was impractical due to poor forage quality and probable livestock aversion. Any planned utilization of little bluestem in August should be preceded by a June defoliation. However, yield from multiple defoliations ( 2 and $3 x$ ) was reduced by over one-half in the second year and appeared to be the treatment which was most detrimental to DM production (Fig. 2). Aftermath yield (October) following a single June or July defoliation was considerably greater than from either multiple defoliations or a single August defoliation. After 2 years of defoliation, a single June or July defoliation produced as much as control plants (Table 2) and accumulated the largest amount of forage by season's end.

Bud numbers under all treatments were equal to those for control plants $\left(285 / \mathrm{m}^{2}\right)$ except for the single July defoliation $\left(622 / \mathrm{m}^{2}\right)$ 
Table 2. Annual dry matter yield and morphology of little bluestem in the second and third years of 2-and 3-year defoliation studies, respectively at the Gudmundsen Sandhills Laboratory.

\begin{tabular}{|c|c|c|c|c|c|c|c|c|}
\hline \multirow[b]{2}{*}{ Parameter } & \multirow[b]{2}{*}{$\begin{array}{l}\text { Year of } \\
\text { study }\end{array}$} & \multirow[b]{2}{*}{$\begin{array}{l}\text { Calendar } \\
\text { year }\end{array}$} & \multicolumn{6}{|c|}{ Month defoliated } \\
\hline & & & $\begin{array}{c}\text { Oct. } \\
\text { (control) }\end{array}$ & June & July & Aug. & $\begin{array}{c}\text { June \& } \\
\text { Aug. }\end{array}$ & $\begin{array}{c}\text { June, July, \& } \\
\text { Aug. }\end{array}$ \\
\hline $\begin{array}{l}\text { Dry matter } \\
\text { yield, } \\
\text { g/plant }\end{array}$ & $\begin{array}{l}\text { Second } \\
\text { Third }\end{array}$ & $\begin{array}{l}1987 \\
1988 \\
1988\end{array}$ & $\begin{array}{l}24.4 \mathrm{a}^{1} \\
22.4 \mathrm{a} \\
24.2 \mathrm{a}\end{array}$ & $\begin{array}{r}9.6 \mathrm{~b} \\
21.5 \mathrm{a} \\
17.3 \mathrm{ab}\end{array}$ & $\begin{array}{r}9.8 \mathrm{~b} \\
18.1 \mathrm{a} \\
22.3 \mathrm{a}\end{array}$ & $\begin{array}{c}3.2 \mathrm{~b} \\
11.7 \mathrm{~b} \\
8.2 \mathrm{bc}\end{array}$ & $\begin{array}{r}6.2 \mathrm{~b} \\
18.1 \mathrm{a} \\
5.5 \mathrm{c}\end{array}$ & $\begin{array}{ll}6.8 & \mathrm{~b} \\
8.3 & \mathrm{~b} \\
3.8 & \mathrm{c}\end{array}$ \\
\hline $\begin{array}{l}\text { Tillers, } \\
\text { number/plant }\end{array}$ & $\begin{array}{l}\text { Second } \\
\text { Third }\end{array}$ & $\begin{array}{l}1987 \\
1988 \\
1988\end{array}$ & $\begin{array}{r}165 \text { a } \\
74 \text { a } \\
144 \text { a }\end{array}$ & $\begin{array}{ll}56 & b \\
87 & a \\
71 & b\end{array}$ & $\begin{array}{r}76 \mathrm{~b} \\
125 \mathrm{a} \\
140 \mathrm{a}\end{array}$ & $\begin{array}{rl}90 & \mathrm{~b} \\
158 & \mathrm{a} \\
88 & \mathrm{~b}\end{array}$ & $\begin{array}{rl}37 & \mathrm{~b} \\
171 & \mathrm{a} \\
56 & \mathrm{~b}\end{array}$ & $\begin{array}{ll}70 & b \\
86 & a \\
64 & b\end{array}$ \\
\hline $\begin{array}{l}\text { Buds, } \\
\text { number/plant }\end{array}$ & $\begin{array}{l}\text { Second } \\
\text { Third }\end{array}$ & $\begin{array}{l}1987 \\
1988 \\
1988\end{array}$ & $\begin{array}{ll}533 & \mathrm{a} \\
285 & \mathrm{~b} \\
547 & \mathrm{a}\end{array}$ & $\begin{array}{c}234 \mathrm{~b} \\
355 \mathrm{ab} \\
316 \mathrm{~b}\end{array}$ & $\begin{array}{ll}180 & b \\
622 & a \\
602 & a\end{array}$ & $\begin{array}{l}221 \mathrm{~b} \\
474 \mathrm{ab} \\
326 \mathrm{~b}\end{array}$ & $\begin{array}{l}202 \mathrm{~b} \\
403 \mathrm{ab} \\
194 \mathrm{~b}\end{array}$ & $\begin{array}{l}264 \mathrm{~b} \\
301 \mathrm{ab} \\
264 \mathrm{~b}\end{array}$ \\
\hline
\end{tabular}

'Numbers in a row, followed by the same letter, are not significantly different at the 0.10 level as determined by Fisher's F-protected L.S.D.

which was significantly higher (Table 2). Tiller numbers were not different among any of the treatments and the control, but tiller weights were higher for control plants than for any treatments. Generally tiller weights increased as tiller numbers decreased, except for the 3-defoliation treatment in which both weight and number were lower. The single defoliations in June or July maintained sufficient tillers and tiller weights to match forage production of the control.

Differences in response that were observed between 2-year periods (1986 and 1987, 1987 and 1988) are partially explained by differences in precipitation. Hyder et al. (1975) determined that most of the significant effects of repeated heavy grazing of shortgrass range were derived from interactions between weather and grazing. Annual precipitation (vegetative season) starting in 1986, 1987 , and 1988 was 202,313 , and $530 \mathrm{~mm}$, respectively, versus a normal of $480 \mathrm{~mm}$. Precipitation distribution was as variable as total amount. In 1986 no precipitation was recorded from January to April and values during the growing season (May to August) were below normal. Precipitation was again below normal in the spring of 1987 and in the first half of the growing season (May to June). In 1988 spring precipitation was near normal and only in August was it below normal during the growing season. Of the 3 years, 1988 was the best for growth and development, based on precipitation data. In the second year of the 2-year data sets, annual DM yields from defoliated plants (except those defoliated 3 times) were 2 times higher in 1988 than in 1987. In 1987 bud numbers under all defoliations were similar to or higher than the control.

Total herbage production from range species is known to be related to precipitation and soil moisture. Heavy grazing interacted with weather to produce large cover changes on a clay upland range site (Launchbaugh 1967). Yield of native, mixed prairie vegetation was influenced by the previous fall soil moisture and current-season precipitation (Rogler and Haas 1947). Total precipitation from the 2 previous years significantly influenced grass yields in a Sandhills range in eastern Colorado (Dahl 1963). Precipitation in May and June gave the highest correlation with range forage production in western Kansas (Hulett and Tomanek 1969). In the case of extreme drought, changes in vegetation may be more drastic than those caused by overgrazing (Branson 1985).

\section{6 through 1988}

Annual DM yield was analyzed for each year of the study due to a year $X$ treatment interaction (Table 2). In the final year of 1988 , the single June and July defoliations were the highest yielding

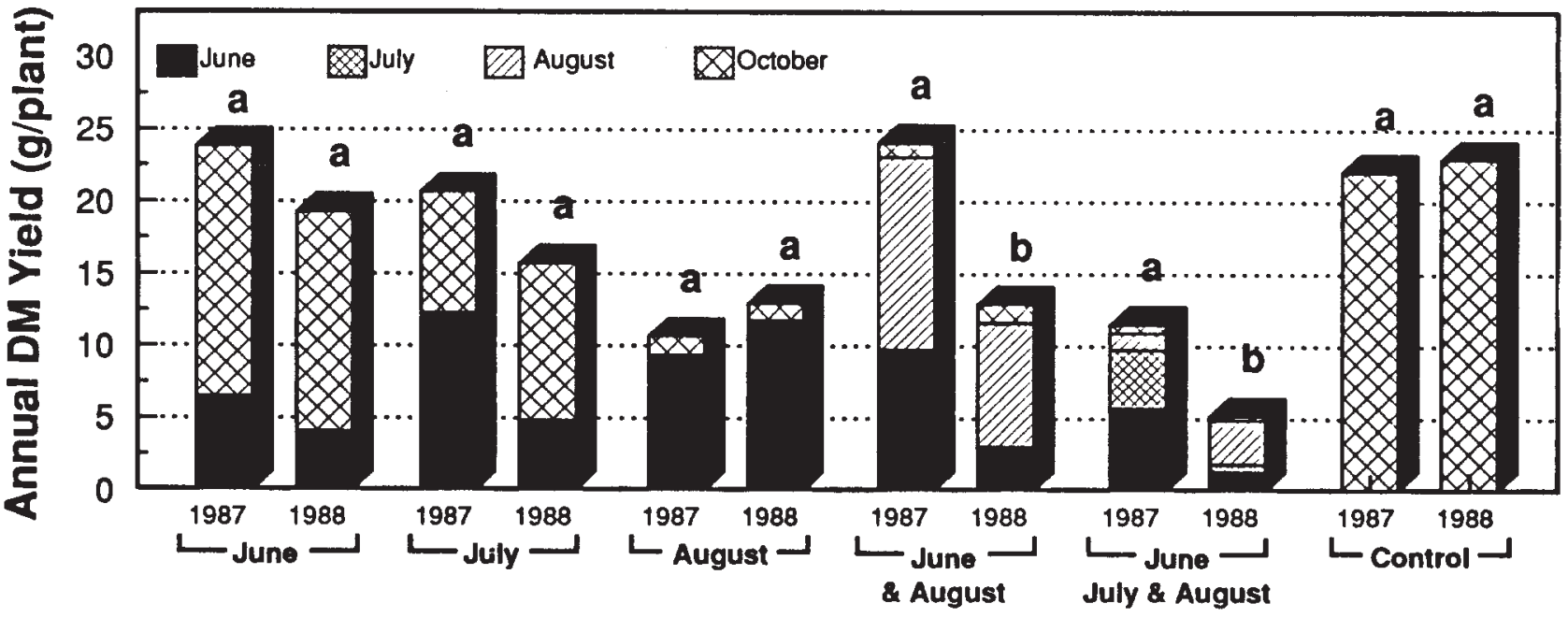

Date of Defoliation

Fig. 2. Annual dry matter (DM) yield of little bluestem defoliated on different dates for 2 years, 1987 and 1988 . Bars within defoliation scheme having the same letter are not significantly different at the 0.01 level as determined by Fischer's F-protected L.S.D. 


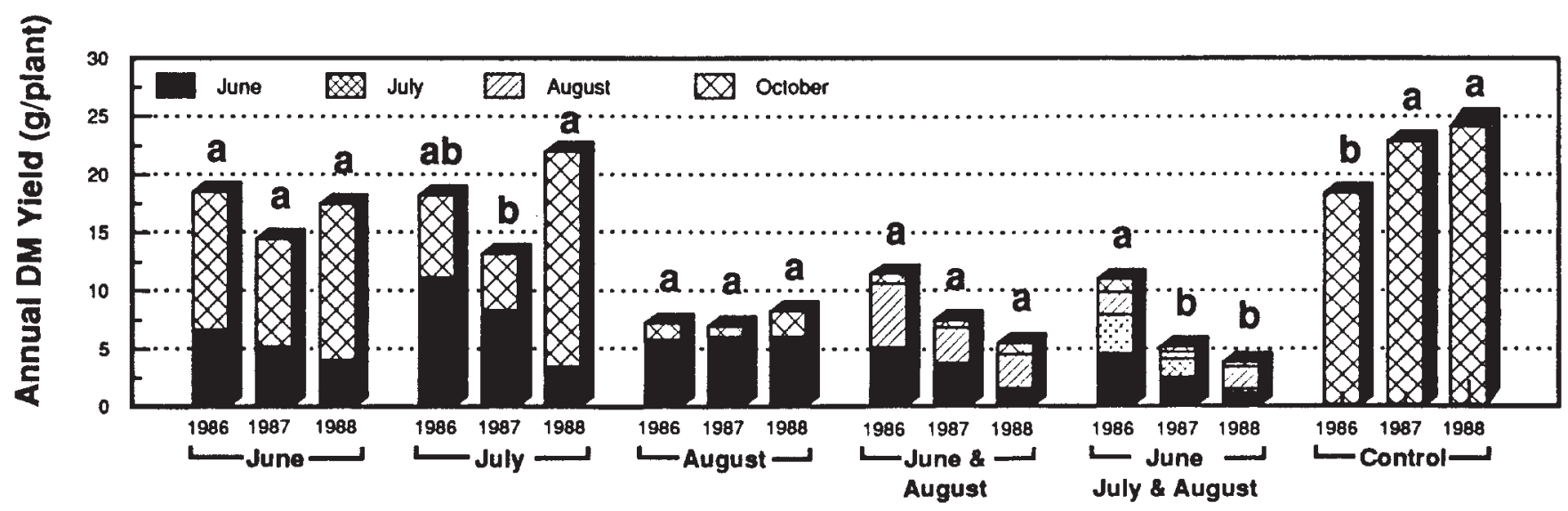

\section{Date of Defoliation}

Fig. 3. Annual dry matter (DM) yield of little bluestem defoliated on different dates for 2 years, 1986 through 1988. Bars within defoliation scheme having the same letter are not significantly different at the 0.01 level as determined by Fischer's F-protected L.S.D.

treatments (17.3 and $22.3 \mathrm{~g} /$ plant, respectively) although neither was different from control $(24.2 \mathrm{~g} /$ plant $)$. Two or 3 defoliations resulted in the lowest yields ( 5.5 and $3.8 \mathrm{~g} /$ plant, respectively) in year 3 although neither treatment was different than a single August defoliation $(3.8 \mathrm{~g} /$ plant $)$. Yield of little bluestem from a single defoliation in July or August increased over years while all other treatments had lower yields in year 3 than year 1 (Fig. 3). Little bluestem could not tolerate close, multiple defoliations over a 3-year period without a severe reduction in total DM yield.

Visual observations of plants defoliated 3 times indicated the center or core had died with herbage production occurring from the periphery of the plant. Three defoliations per growing season may be beneficial when trying to reduce the physical barrier formed by large undefoliated plants. Allowing only the periphery to survive could create several new plants (clumps) from 1 large plant, previously reported by Butler and Briske (1988).

Bud number was reduced by all defoliations except the single defoliation in June (Table 2). Tiller numbers were significantly higher for control plants (144/plant) and under a single July defoliation (140/plant) than under other treatments (Table 2). Defoliation treatments which reduced bud numbers after 3 years also reduced tiller numbers. Tiller weight was greatest under the single June defoliation and least under the 3-defoliation treatment. A single defoliation early in the growing season resulted in fewer tillers but those tillers present were heavier. Three years of multiple defoliations reduced both tiller number (60/plant) and tiller weight ( $77 \mathrm{mg} /$ tiller) producing a highly detrimental effect on annual DM yield. Little bluestem did not tolerate close, frequent defoliations for 3 years.

\section{Conclusion}

In the first year all defoliated plants produced significantly less annual DM yield than control plants although bud and tiller numbers were similar. Second year cumulative responses were affected by precipitation: in 1987, a dry year, control plants produced more annual DM yield, tillers, and buds than defoliated plants. But, in 1988, an above-normal precipitation year, single early defoliations produced yields and bud and tiller numbers as high as controls. Three years of single defoliations in June or July produced DM yields in the third year similar to those of control plants, but single August or multiple defoliations severely reduced annual DM yield, tiller number, tiller weight, and bud number. Preferably, little bluestem should be defoliated a single time in June or July. A single July defoliation was the optimum treatment for total DM vield tiller weight and numher and hud number nus to reduced forage quality, plants grazed late in the growing season should also be grazed in June. To insure restoration of plant vigor, plants grazed late in the growing season should not be grazed closely every year and multiple defoliations should not be repeated in consecutive years unless the purpose was to weaken large plants so that remaining tillers at the periphery would form new, smaller little bluestem plants.

\section{Literature Cited}

Branson, F.R. 1985. Vegetation changes on western rangelands. Soc. Range Manage. Denver, Colo.

Butler, J.L., and D.D. Briske. 1988. Population structure and tiller demography of the bunchgrass Schizachyriam scoparium in response to herbivory. Oikos 51:306-312.

Buwai, M., and M.J. Trlica. 1977. Multiple defoliation effects on herbage yield, vigor, and total nonstructural carbohydrates of five range species. J. Range Manage. 30:164-172.

Dahl, B.E. 1963. Soil moisture as a predictive index to forage yield for the Sandhills range type. J. Range Manage. 23:103-108.

Dwyer, D.D., W.C. Elder, and G. Singh. 1963. Effects of height and frequency of clipping of pure stands of range grasses in north central Oklahoma. Agr. Exp. Sta. Bull. B-64.

Gilbert, W.L. 1976. Dry matter accumulation and forage quality of four warm-season grasses in the Nebraska Sandhills. Ph.D. Thesis, Univ. Nebraska, Lincoln.

Hulett, G.K., and G.W. Tomanek. 1969. Forage production on a clay upland site in western Kansas. J. Range Manage. 22:270-276.

Hyder, D.N., R.E. Bement, E.E. Remmenga, and D.F. Hervey. 1975. Ecological responses of native plants and guidelines for management of shortgrass range. USDA Tech. Bull. 1503.

Launchbaugh, J.L. 1967. Vegetation relationships associated with intensity of summer grazing on a clay upland range site in the Kansas 20- to 24-inch precipitation zone. Kansas Agr. Exp. Sta. Tech. Bull. 154.

Moser, L.E., and L.J. Perry. 1983. Yield, vigor, and persistence of sand lovegrass [Eragrostis trichodes (Nutt.) Wood] following clipping treatments. J. Range Manage. 36:236-238.

Owensby, C., J.R. Rains, and J.D. McKendrick. 1974. Effects of one year of intensive clipping on big bluestem. J. Range Manage. 27:341-343.

Reed, J.L., and D.D. Dwyer. 1971. Blue grama response to nitrogen and clipping under two soil moisture levels. J. Range Manage. 24:47-51.

Rogler, G.A., and H.J. Haas. 1947. Range production as related to soil moisture and precipitation on the Northern Great Plains. J. Amer. Soc. Agron. 39:378-389.

SAS. 1982. SAS User's Guide: Statistics. SAS Inst., Inc., Cary, N.C.

Stoddart, L.A. 1946. Some physical and chemical response of Agropyron spicatum to herbage removal at various seasons. Utah Agr. Exp. Sta. Bull. 324.

Turner, G.T., and G.E. Klipple. 1952. Growth characteristics of blue grama in northeastern Colorado. J. Range Manage. 5:22-28.

Undersander, D.J., and C.H. Naylor. 1987. Influence of clipping frequency on herbage yield and nutrient content of tall wheatgrass. J. Range Ivrallagu. $+0.0 x-20$. 